\title{
APLIKASI PENGELOLAAN DATA PASIEN DI APOTEK BERBASIS ANDROID
}

\author{
Rizal Dzulkarnaen ${ }^{1}$, Ridha Kurniawan ${ }^{2}$ \\ Program Studi Teknik Informatika STMIK "AMIKBANDUNG" \\ Jln. Jakarta No. 28 Bandung 40272 INDONESIA \\ rizal@stmik-amikbandung.ac.id ${ }^{1}, \underline{\text { Kurniawan.ridha507@gmail.com }}^{2}$
}

\begin{abstract}
Abstrak
Kemajuan era globalisasi saat ini, membuat persaingan antar individu bahkan antar perusahaan semakin ketat, sehingga mereka berlomba - lomba membangun kekuatan dengan banyak cara. Salah satu caranya adalah dengan menggunakan sebuah sistem berbasis smartphone untuk meningkatkan rating qualitasnya.Sebuah sistem yang dengan itu perusahaan dapat terasa lebih dekat dengan para konsumen. Sistem yang membuat perusahaan juga mampu mengelola data para konsumen, sehingga perusahaan dapat membuat kebijakan - kebijakan selanjutnya demi meningkatkan kepuasan para konsumen.Pemakaian sistem ini pun juga baik untuk diterapkan pada perusahaan kecil, sebagai contoh apotek. Dalam proses bisnis apotek sebelumnya adalah menggunakan komponen kertas sebagai pendataan data pasien dan resep obat pasien sehingga bila terus berlanjut maka apotek akan mengeluarkan banyak pengeluaran kertas dan tetap tidak meningkatkan kenyamanan pasien.Maka dengan melihat proses bisnis yang masih berjalan ini, penulis berniat menjadikannya sebagai bahan untuk tugas akhir. Dalam tugas akhir ini akan dibuatkan sebuah aplikasi yang dapat membantu apotek meningkatkan keuntungan serta pengelolaan data dengan baik sehingga dapat membuat kebijakan - kebijakan untuk memajukan apotek.
\end{abstract}

Kata kunci- Aplikasi, Android, Pengelolaan Data, Pasien, Apotek.

\begin{abstract}
The globalitation era make competition between personal or company getting closer, so that each other compete gain the power with many ways. One of the ways is take a basic system of smartphone to increase quality rating. The system make a company looks like near with the consumen and be managing data of them. That will be company is easy to get a good decision for improve satisfaction of consumen. Usage system can too be apply on the small company as simple pharmacy. The proceses business pharmacy is also use papper on record data and recipe of patient before, so if that always on can make lot consumption of paper and not to be increase comfort patient. Then after view the process bisuness work, writer want be this cause as stuff to be final project. On the final project will be build the program what can help increase benefit and good manage data so that can make best decision for pharmacy at the future.
\end{abstract}

Keywords - Application, Android, manage Data, Patient, Pharmacy

\section{PENDAhULUAN}

Pada zaman ini seluruh kegiatan umat manusia telah banyak bersentuhan dengan suatu benda yang dapat menambah keuntungan dan mengurangi usaha. Sesuatu yang membuat dari awalnya jauh menjadi dekat, dari awalnya besar menjadi kecil, dan dari awalnya berat menjadi ringan, Sesuatu itu adalah teknologi. Peran teknologi remaja ini sudah tidak dapat lagi dianggap sebelah mata, 
JURNAL BUFFER INFORMATIKA

Volume 5 Nomor 2, Oktober 2019
p-ISSN : 2527-4856, e-ISSN : 2614-5413

https://journal.uniku.ac.id/index.php/buffer karena kehadirannya sangat dibutuhkan dalam menyelesaikan ataupun meringkas sebuah masalah.

Teknologi sekarang ini timbul akibat banyaknya masalah-masalah yang terjadi pada kegiatan manusia dari awal bangun hingga kembali istirahat untuk tidur. Teknologi sekarang pun tak lepas dari perkembanganperkembangan yang terjadi tiap tahunnya atau lebih cepat lagi, untuk lebih memberikan keuntungan dan manfaat yang berlipat-lipat dari sebelumnya. Salah satu perkembangan teknologi yang sedang diminati untuk dilakukan pengembangan adalah teknologi smartphone.

Teknologi smartphone adalah teknologi hasil perpaduan antara teknologi komputer dengan tekhnologi handphone, sehingga teknologi ini sangat diminati oleh kebanyakan masyarakat di segala kegiatan dikarenakan kemudahan mengaksesnya dan kemampuannya yang mendekati teknologi komputer. Teknologi inilah yang menjadi salah satu perangkat yang sangat dianggap penting dalam dunia bisnis, terutama untuk para pebisnis yang harus mengetahui secara langsung perkembangan bisnisnya. Teknologi ini pula sangat berguna sekali bagi para pengusaha ukm kecil, karena dapat membantu dalam kemudahan pencatatan data dan kemudahan dalam berkomunikasi.

Pada daerah sekitar dayeuh kolot terdapat banyak ukm yang tersebar namun belum menggunakan kemajuan tekhnologi ini secara baik dan maksimal, dapat kita ambil contoh yaitu apotek. Pada apotek di sekitar daerah dayeuh kolot sudah banyak apotek yang bukan hanya menjual obat saja namun sudah memberikan fasilitas dokter umum dalam melakukan pemeriksaan tahap awal pada masyarakat yang terserang penyakit. Dalam prakteknya apotek-apotek ini masih menggunakan cara manual dalam menangani pendataan pasien yang berobat dan juga hasil pemeriksaannya. Sistem yang digunakan masih menggunakan cara umum yaitu dokter melakukan pemeriksaan setelah itu dokter menuliskan diagnosa, analisis, serta resep obat terhadap hasil pemeriksaan, setelah itu hasil itu diberikan kepada pasien untuk diserahkan ke bagian apoteker sehingga membuat pasien disibukkan dengan sistem yang berjalan dan mengurangi nilai pelayanan apotek tersebut juga menambah beban apotek untuk pmelakukan penyimpanan data rekap medis pasien. Dari permasalahanyang telah dipaparkan, bila apotek bisa melakukan perbaikan sistem dan pendataan rekap medis pasien lebih rapih maka akan meningkatkan kepercayaan masyarakat terhadap pelayanan di apotek.

Oleh karena itu dari pemaparan diatas akhirnya saya sebagai mahasiswa stmik amik bandung yang sedang mengambil tugas akhir, ingin memadukan keunggulan-kenggulan yang dimiliki smartphone pada kegiatan bisnis usaha kecil dan menegah yaitu pada apotek. Yang mana saya akan melakukan pembuatan sebuah aplikasi yang akan membantu dalam kegiatan-kegiatan bisnis di apotek dalam hal pendataan data pasien dan data hasil pemeriksan pasien.Dengan itu saya akan memberikan judul tugas akhir saya ini dengan "aplikasi pengelolaan data pasien di apotek berbasis android".

Berdasarkan dari penjelasan latar belakang diatas, maka dapat diidentifikasi suatu permasalahan yaitu pada umumnya masih banyak apotek yang memakai cara manual dalam melakukan sebuah pengelolaan data para pasien sehingga akan terjadi masalah dalam jangka panjang. Juga masalah umum yang sering terjadi dari pihak apotek yang mengeluhkan dan menginginkan adanya aplikasi yang memudahan dalam pengelolaan juga penyimpanan data hasil pemeriksaan agar meningkatkan pelayanan di apotek.

Berdasarkan dari uraian latar belakang di atas maka dapat dirumuskan suatu permasalahan.

1. Bagaimana membuat aplikasi pengelolaan data pasien yang dapat mempermudah pengelolaan data pasien di sebuah apotek?

2. Bagaimana cara membuat aplikasi pengelolaan data pasien yang dapat membantu dalam peyimpanan data hasil pemeriksaan agar memudahkan dalam meningkatkan pelayanan di apotek?

Agar dalam pengerjaan tugas akhir ini dapat lebih terarah, maka pembahasan penulisan ini dibatasi pada ruang lingkup pembahasan sebagai berikut: 
p-ISSN : 2527-4856, e-ISSN : 2614-5413

https://journal.uniku.ac.id/index.php/buffer
1. Studi kasus pembuatan aplikasi ini adalah dari beberapa apotek di daerah dayeuhkolot.

2. Aplikasi ini dibuat hanya untuk apotek dengan satu dokter umum.

3. Aplikasi yang dibuat hanya untuk apotek yang measih menggunakan cara manual dalam pendataan pemeriksaan pasien.

4. Aplikasi ini menggunakan minimum sdk platform android 2.3.

5. Aplikasi ini tidak berhubungan dengan pembayaran biaya periksa dan pengiriman resep obat.

6. Aplikasi ini hanya menampilkan data sesui data pasien, tidak dapat menampilkan data secara keseluruhan.

\subsection{Android}

Android adalah system operasi yang berbasis Linux untuk telepon seluler seperti telepon pintar dan komputer tablet. Android menyediakan platform terbuka bagi para pengembang untuk menciptakan aplikasi mereka sendiri untuk digunakan oleh bermacam peranti bergerak. Awalnya, Google Inc. membeli Android Inc., pendatang baru yang membuat peranti lunak untuk ponsel. Kemudian untuk mengembangkan Android, dibentuklah Open Handset Alliance, konsorsium dari 34 perusahaan peranti keras, peranti lunak, dan telekomunikasi, termasuk Google, HTC, Intel, Motorola, Qualcomm, T-Mobile, dan Nvidia.

Pada saat perilisan perdana android, 5 november 2007, android bersama Open Handset Alliance menyatakan mendukung pengembangan standar terbuka pada perangkat seluler. Di lain pihak, Google merilis kode-kode Android di bawah lisensi Apache, sebuah lisensi perangkat lunak dan standar terbuka perangkat seluler.

Di dunia ini terdapat dua jenis distributor sistem operasi Android. Pertama yang mendapat dukungan penuh dari Google atau Google Mail Services (GMS) dan kedua adalah yang benarbenar bebas distribusinya tanpa dukungan langsung Google atau dikenal sebagai Open Handset Distribution (OHD)[1].

\section{2 Хатрр}

Menurut Puspitasari berpendapat bahwa XAMPP adalah sebuah softwarewebserver apache yang didalamnya sudah tersedia database server mysql dan support php programming. xampp merupakan software yang mudah digunakan gratis dan mendukung instalasi di linux dan windows. Keuntungan lainya adalah cuma menginstal 1 kali sudah tersedia apache web server, mysql database server, php support (php4 dan php5) dan beberapa modul lainya hanya bedanya kalau versi windows selalu dalam bentuk instalasi grafis dan yang linux dalam bentuk file terkompresi tar.gz. kelebihan lain yang berbeda dari versi untuk windows adalah memeliki fitur untuk mengaktifkan sebuah server secara grafis, sedangkan linux masih berupa perintahperintah didalam console. oleh karena itu versi untuk linux sulit untuk dioperasikan".[3]

Menurut Kartini dalam paketnya sudah terdapat Apache (web server), MySQL (database), PHP (server side scripting), Perl, FTP server, Php MyAdmin dan berbagai pustaka bantu lainnya. Dengan menginstall XAMPP maka tidak perlu lagi melakukan instalasi dan konfigurasi web server Apache, PHP dan MySQL secara manual. XAMPP akan menginstalasi dan mengkonfigurasikannya secara otomatis untuk anda. XAMPP adalah sebuah web server. Asal kata dari XAMPP sendiri adalah:

1. (X) : Program ini dapat dijalankan dibanyak sistem operasi.

2. (A): Apache merupakan suatu aplikasi web server.

3. (M): MySQL digunakan untuk aplikasi database server.

4. (P) : PHP bahasa pemrograman yang dipakai.

5. (P) : Perl bahasa pemrograman yang dipakai.[8]

\subsection{Smartphone}

Smartphone atau ponsel cerdas merupakan kombinasi dari PDA dan ponsel, namun lebih berfokus pada 
JURNAL BUFFER INFORMATIKA

Volume 5 Nomor 2, Oktober 2019

bagian ponselnya. Smartphone ini mengintegrasikan kemampuan ponsel dengan fitur komputer-PDA. Smartphone mampu menyimpan informasi, e-mail, dan instalasi program, seperti menggunakan mobile phone dalam satu device. Smartphone biasanya berorientasi pada fitur ponsel dibanding dengan fitur PDA. Sebagian besar perangkat mobile yang melebihi kemampuan ponsel dapat dikategorikan sebagai Smartphone. Banyak yang mendefinisikan smartphone adalah ponsel yang didalamnya berisi inovasi gadget termutakhir.[4]

\subsection{Prototype System Development Life Cycle(SDLC)}

Prototyping sebagai suatu paradigma baru dalam pengembangan sistem informasi akuntansi, tidak hanya sekedar suatu evolusi dari metode pengembangan sistem informasi yang sudah ada tetapi sekaligus merupakan revolusi dalam pengembangan sistem informasi akuntansi[5].

Urutan SDLC Prototype ini bersifat serial dari proses pengumpulan bahan, perancangan, dan evaluasi.

1. Pengumpulan kebutuhan:

Pengumpulan kebutuhan dilakukan dengan cara survey ke beberapa apotek sekitar daerah Dayeuhkolot.

2. Perancangan: perancangan dilakukan dengan rancangan mewakili semua aspek software yang telah diketahui seperti data pasien berupa nama, tanggal lahir, dan alamat. Setalah semuanya terkumpul maka aplikasi akan dibuat dengan design prototype-nya terlebih dahulu.

3. Evaluasi Prototype: Prototype yang telah jadi akan diujicobakan kepada client yang nantinya mereka memberi laporan tentang apa saja yang berhubungan dengan aplikasi yang telah dibuat, sehingga dengan begitu dari sisi developer dapat mengetahui kekurangan-kekurangan yang ada di aplikasi tersebut.

Tahap maintenance. Pada tahap ini aplikasi sudah berada ditangan user.
p-ISSN : 2527-4856, e-ISSN : 2614-5413

https://journal.uniku.ac.id/index.php/buffer

Tujuan dari tahap ini adalah agar informasi data yang diberikan kepada user selalu bertambah dan mengamati agar aplikasi dapat terus berjalan dengan baik.

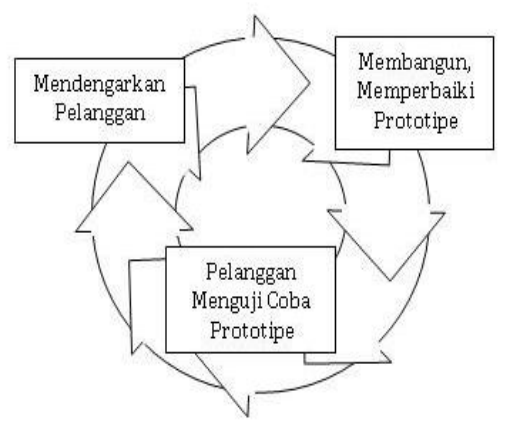

Gambar 1. Model Prototype

\subsection{Pengujian Blackcox}

Pengujian blackbox adalah pengujian aplikasi yang dilakukan sebagai user, apa yang umumnya pengguna lihat pada aplikasi yang digunakan tanpa harus melihat isi dari coding-an dari aplikasi tersebut[6].

Blackbox hanya menjalankan dan mengeksekusi unit atau modul kemudian diamati apakah sesuai dengan proses bisnis yang dibuat atau tidak. Dengan kata lain, blackbox merupakan user testing perangkat lunak yang melibatkan client untuk melihat apakah sesuai dengan yang diharapkan atau tidak aplikasi yang diinginkan.

Blackbox testing melakukan pengujian tanpa mengetahui struktur detail internal dari sistem atau komponen yang akan dites.

1.6 Definisi Apotek

Menurut keputusan Menteri Kesehatan Republik Indonesia Nomor 1332/Menkes/SK/X/2002 Tentang Perubahan Peraturan Menteri Kesehatan 922/Menkes/Per/X/1993 Tentang Ketentuan dan Tata Cara Pemberian Izin Apotek Pasal 1 Ayat (a): "Apotek adalah suatu tempat tertentu, tempat dilakukannya pekerjaan kefarmasian dan penyaluran sediaan farmasi. Perbekalan kesehatan lainnya kepada masyarakat". 


\subsection{Definisi Pasien}

Pasal 1 Undang-undang No. 29 Tahun 2004 Tentang praktik kedokteran menjelaskan definisi pasien adalah setiap orang yang melakukan konsultasi masalah kesehatannya untuk memperoleh pelayanan kesehatan yang diperlukan baik secara langsung maupun tidak langsung kepada dokter atau dokter gigi.

\section{METODE PENELITIAN}

\subsection{Analisis}

Analisis sistem di defenisikan sebagai bagaimana memahami dan menspefikasi dengan detail apa yg harus di lakukan oleh sistem. Sementara sistem desain di artikan sebagai menjelaskan dengan detail bagaimana bagian-bagian dari sistem informasi di implementasikan. Dengan demikian analisis dan desain sistem informasi (ANSI) bisa di defenisikan sebagai : proses organisasional kompleks di mana sistem informasi berbasis komputer di implementasikan. sistem analisis adalah profesi yg menantang karena menggabungkan banyak keahlian seperti keahlian analisis,teknis,interpersonal dan manajerial.

\subsubsection{Analisis Sistem}

Analisis sistem adalah penguraian dari suatu sistem yang utuh ke dalam bagian-bagian komponennya dengan maksud untuk mengidentifikasi dan mengevaluasi permasalahan. Bagian analisis ini terdiri atas analisis fungsional, gambaran sistem dari sudut pandang user yang dinyatakan dalam use case diagram.

\subsubsection{Analisis Fungsionalitas}

Analisis fungsional di sini terdapat user yang akan mengakses aplikasi pengelolaan data pasien ini. Pada aplikasi berbasis Android ini, user dapat melihat beberapa fitur antara lain:

1. Mampu melihat data hasil pemeriksaan dan resep.

2. Mampu menampilkan history pemeriksaan dengan mudah dan
p-ISSN : 2527-4856, e-ISSN : 2614-5413

https://journal.uniku.ac.id/index.php/buffer

cepat walau pasien sudah lama tak berobat di apotek yang sama.

\subsubsection{Kebutuhan Fungsionalitas}

Kebutuhan Fungsional adalah, merupakan kebutuhan yang harus dipenuhi oleh perangkat lunak yang akan dibangun. Kebutuhan fungsional tersebut akan mengalami pendeskripsian dalam bentuk tabeltabel, yaitu sebagai berikut :

Tabel 1 Kebutuhan Fungsional User

\begin{tabular}{|l|l|l|}
\hline $\begin{array}{l}\text { No. } \\
\text { SRS }\end{array}$ & User & $\begin{array}{l}\text { Deskripsi } \\
\text { Kebutuhan }\end{array}$ \\
\hline SRS F-1 & $\begin{array}{l}\text { Bag. } \\
\text { Pendafataran }\end{array}$ & Login User \\
\hline SRS F-2 & $\begin{array}{l}\text { Bag. } \\
\text { Pendafataran }\end{array}$ & $\begin{array}{l}\text { Mengelola Data } \\
\text { Pendaftaran } \\
\text { Pasien. }\end{array}$ \\
\hline SRS F-3 & Dokter & Login User \\
\hline SRS F-4 & Dokter & View Data Pasien \\
\hline SRS F-5 & Dokter & $\begin{array}{l}\text { Input Rekam } \\
\text { Medis }\end{array}$ \\
\hline SRS F-6 & Apoteker & Login User \\
\hline SRS F-7 & Apoteker & View Resep Obat \\
\hline
\end{tabular}

\subsubsection{Definisi Aktor}

Adapun definisi actor dalam sistem ini adalah sebagai berikut :

Tabel 2 Definisi Aktor

\begin{tabular}{|l|l|l|}
\hline Kode & Aktor & \multicolumn{1}{|c|}{ Deskripsi } \\
\hline A-01 & $\begin{array}{l}\text { Bag. } \\
\text { Pendaftaran }\end{array}$ & $\begin{array}{l}\text { User yang dapat } \\
\text { melakukan } \\
\text { pengelolaan data } \\
\text { pendaftaran pasien. }\end{array}$ \\
\hline A-02 & Dokter & $\begin{array}{l}\text { User yang dapat } \\
\text { melakukan input data } \\
\text { rekam medis dan } \\
\text { melihat data pasien }\end{array}$ \\
\hline A-03 & Apoteker & $\begin{array}{l}\text { User yang dapat } \\
\text { melihat data resep obat }\end{array}$ \\
\hline
\end{tabular}

\subsubsection{Use Case Diagram}

Use case merupakan gambaran skenario dari interaksi antara user dengan sistem. Sebuah use case 
diagram menggambarkan hubungan antara aktor dan kegiatan yang dapat dilakukannya terhadap aplikasi.

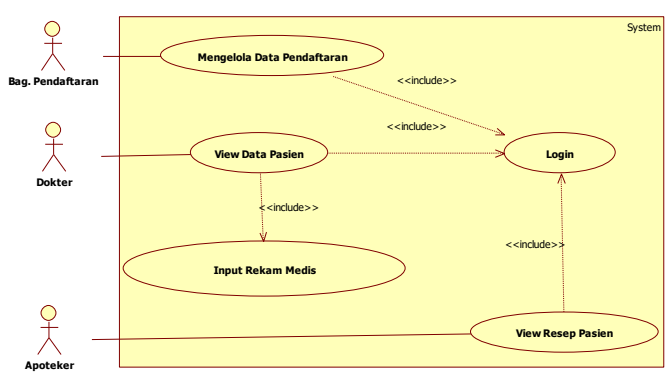

Gambar 2. Use Case Diagram

Use Case Diagram di atas menjelaskan kegiatan dari beberapa user kepada sistem yang dibangun adalah terdapat 3 user yang berbeda dan memiliki funsionalitas sendiri namun tetap berhubungan. Bagian pendaftaran hanya dapat melakukan pengelolaan data pendafataran pasien, dokter dapat melihat data pasien yang terdaftar dan dapat melakukan input rekam medis, terakhir apoteker hanya dapat melihat data resep pasien. semua kegiatan ini tersambung pada satu server sehingga memudahkan dalam melakukan pendataan yang terstruktur.

\subsubsection{Class Diagram}

Berikut adalah class diagram yang didapat dari sistem yang dibangun :

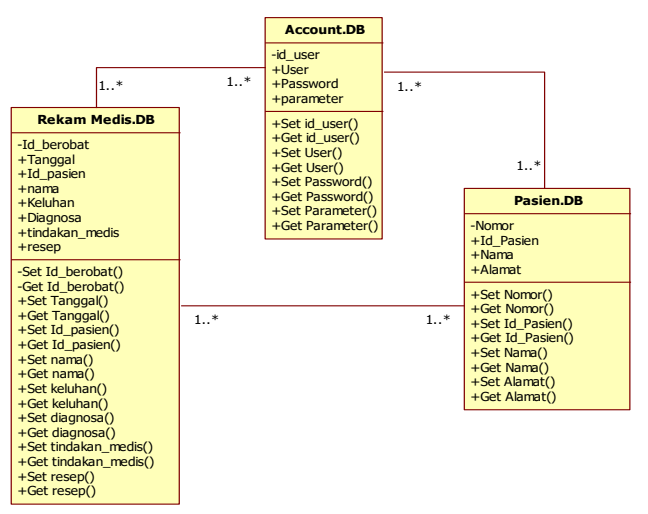

Gambar 3. Class Diagram
p-ISSN : 2527-4856, e-ISSN : 2614-5413

https://journal.uniku.ac.id/index.php/buffer

Pada class diagram diatas menunjukan hubungan relasi antar class yang saling berhubungan sehingga program bisa berjalan sesuai fungsinya. Pada class diagram ini juga di tunjukkan attribute pendukung aktivitas setiap kelas sehingga mempermudah bagi developer selanjutnya.

\subsection{Perancangan}

\subsubsection{Perancangan Sistem Perangkat Keras}

Untuk menjalankan aplikasi ini dibutuhkan Smartphone dengan sistem operasi Android, dengan spesifikasi seperti berikut:

1. Handphone Android

2. Sistem operasi Android 2.3

3. RAM $512 \mathrm{MB}$

4. CPU ARMv6

\subsubsection{Perancangan Sistem Perangkat Lunak}

Pada analisis kebutuhan aplikasi ini adalah kebutuhan yang akan mendukung proses pembuatan sistem aplikasi rumah makan ini.

1. Kebutuhan perangkat lunak pada aplikasi pengelolaan data pasien ini adalah sebagai berikut:

Tabel 3 Perancangan Sistem Perangkat Lunak

\begin{tabular}{|l|l|l|}
\hline No. & Spesifikasi \\
\hline 1 & Sistem Operasi & Windows 7 \\
\hline 2 & Emulator Android & Android SDK \\
\hline 3 & Editor Code & IDE Eclipse \\
\hline 4 & UML Design & Star UML \\
\hline 5 & Dokumentasi & Ms. Word \\
\hline
\end{tabular}

\subsubsection{Gambaran Sistem}

Di bawah ini akan dijelaskan sebuah gambaran sistem yang akan dibuat. Dari gambaran sistem yang ada dapat dilihat sebuah desain aplikasi pada gambar di bawah ini. 
JURNAL BUFFER INFORMATIKA

Volume 5 Nomor 2, Oktober 2019

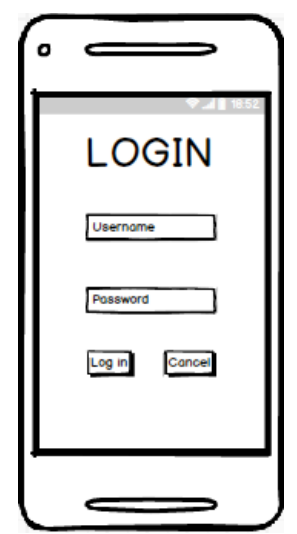

Gambar 4. Gambaran Login

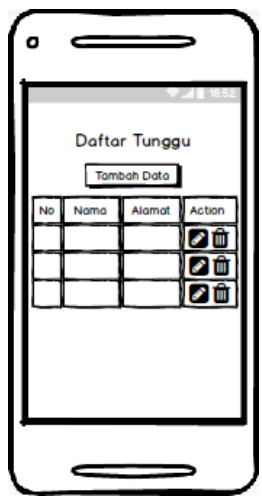

Gambar 5. Gambaran Tampilan Data Pasien

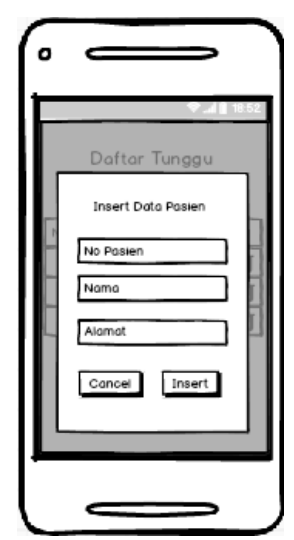

Gambar 6. Gambaran Mengelola Data Pasien (Add)
p-ISSN : 2527-4856, e-ISSN : 2614-5413

https://journal.uniku.ac.id/index.php/buffer

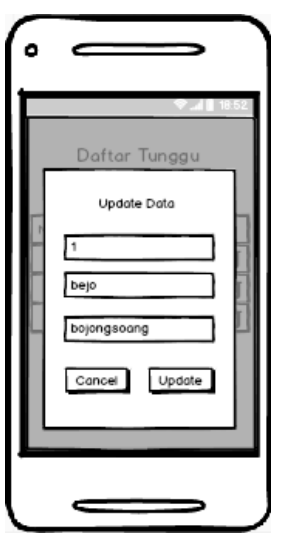

Gambar 7. Gambaran Mengelola Data Pasien (Update)

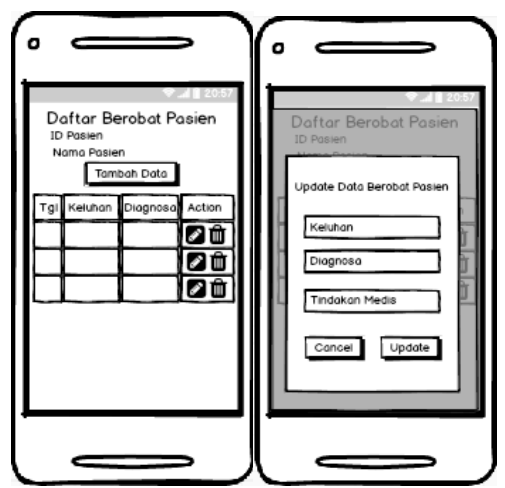

Gambar 8. Gambaran Mengelola Data Berobat Pasien (Update)

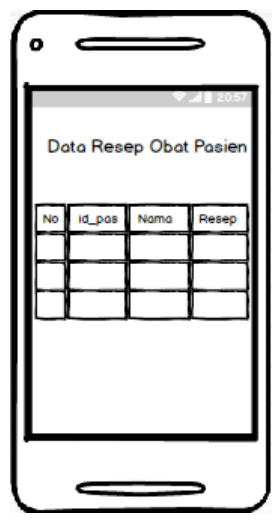

Gambar 9. Gambaran Tampilan Resep Pasien 


\section{HASIL DAN PEMBAHASAN}

\subsection{Implementasi}

\subsubsection{Instalasi Program}

Pada aplikasi ini telah di compile dan build dengan menggunakan software pembangunan aplikasi eclipse dan telah berbentuk apk. untuk melakukan instalasi, salin file ekstensi "finalprojectS1.apk" pada penyimpanan smartphone lalu kemudian install file di dalam smartphone dan setelah itu jalankan file tersebut. Pastikan alamat sever sudah sesuai dengan inputan alamt server pada code program.

\subsubsection{Tampilan Aplikasi}

Tampilan awal pada saat aplikasi baru dijalankan

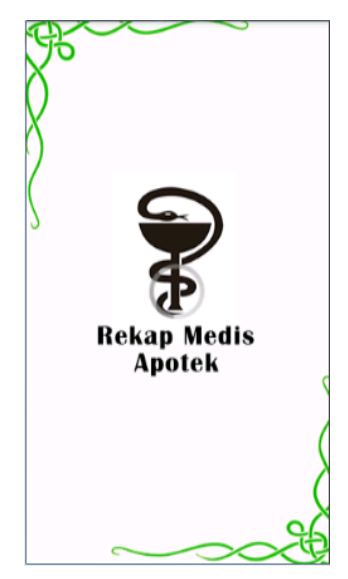

Gambar 10. Tampilan Opening Aplikasi

Pada gambar 10 merupakan opening dari aplikasi yang dijalankan. Pada tampilan ini aplikasi sedang melakukan loading sebelum masuk ke aplikasi utama.
p-ISSN : 2527-4856, e-ISSN : 2614-5413

https://journal.uniku.ac.id/index.php/buffer

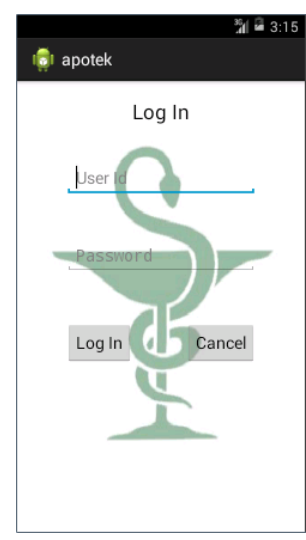

Gambar 11. Tampilan Login Aplikasi

Gambar 11 merupakan tampilan awal sebelum masuk kedalam aplikasi, user harus memasukkan data username dan password yang sesuai. Data pemakai aplikasi berada dalam data table login pada database.

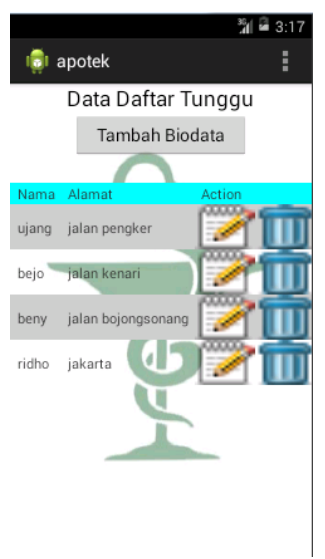

Gambar 12. Tampilan Data Pasien Yang Mendaftar

Tampilan 12 merupakan awal tampilan setelah melakukan login kasir, akan disajikan tampilan data - data pasien yang telah mendaftar berupa tabel dan tombol action. 
JURNAL BUFFER INFORMATIKA

Volume 5 Nomor 2, Oktober 2019

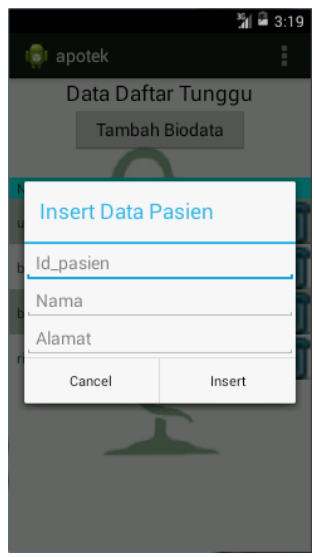

Gambar 13. Tampilan Form Add Data Pasien

Gambar 13 merupakan tampilan form untuk melakukan pendataan pasien baru yang dilakukan pada kasir untuk mendaftar sebelum pemeriksaan.

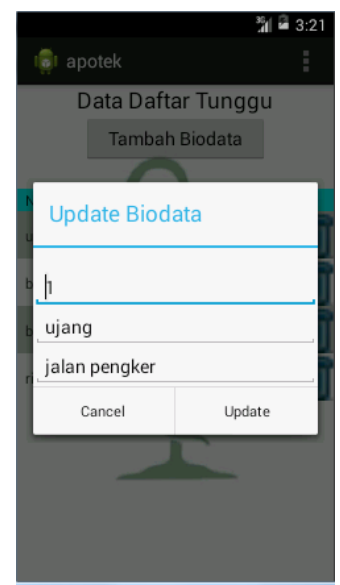

Gbr 14 Tampilan Menu Update Data Pasien

Gambar 14 merupan tampilan melakukan pengelolaan data pasien berupa kegiatan update.
p-ISSN : 2527-4856, e-ISSN : 2614-5413

https://journal.uniku.ac.id/index.php/buffer

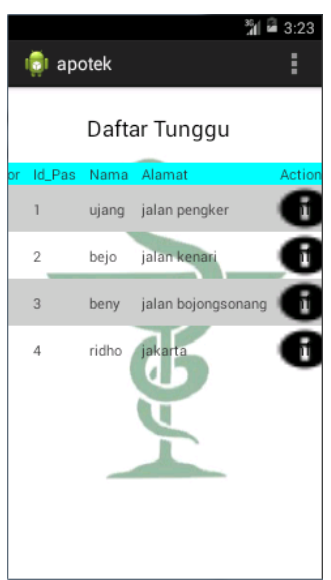

Gambar 15. Tampilan Data Pasien Pada Dokter

Gambar 15 adalah tampilan table data pasien ini adalah tampilan yang akan dimunculkan sistem bilamana dalam login user menggunakan login dokter dan dalam melakukan pendataan pemeriksaan melakukan tekan tombol info.

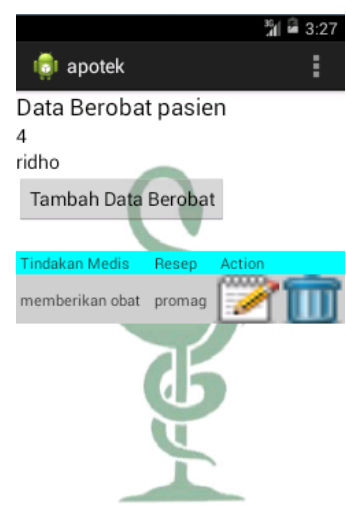

Gambar 16. Tampilan Data Berobat Pasien

Gambar 16 adalah hasil dari tampilan data detail pemeriksaan data pasien berupa table. Seluruh data hasil berobat pasien yang telah ditentukan akan ditampilkan. 


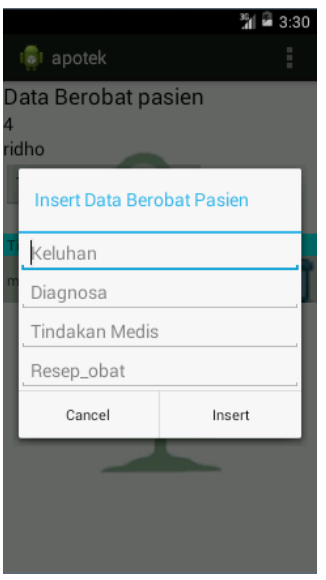

Gambar 17. Tampilan Form Add Data Berobat Pasien

Gambar 17 adalah tampilan form tambah data berobat pasien yang mana akan dilakukan untuk mencatat data hasil berobat pasien.

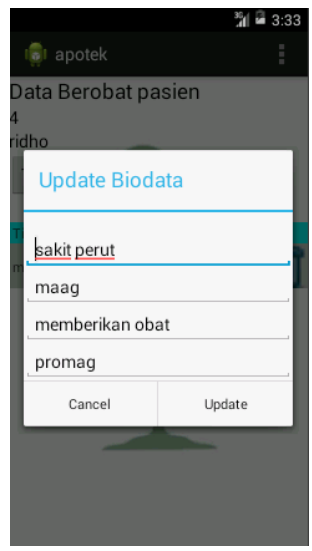

Gambar 18. Tampilan Menu Update Data Berobat Pasien

Gambar 18 adalah penampilan kegiatan mengelola update data berobat pasien. Dengan mememasukkan data yang benar setelah terjadi kesalahan memasukkan data.
p-ISSN : 2527-4856, e-ISSN : 2614-5413

https://journal.uniku.ac.id/index.php/buffer

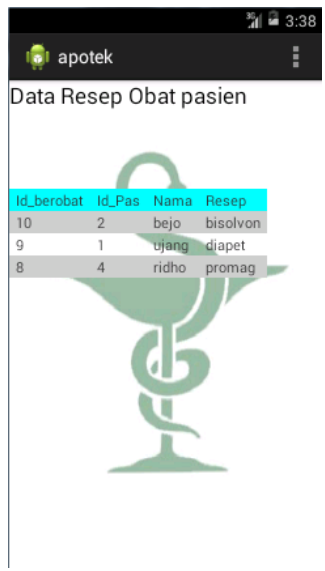

Gambar 19. Tampilan Data Resep Pasien

Gambar 19 adalah tampilan table data resep pasien. Setelah dokter melakukan pemeriksaan pada pasien maka apoteker dapat melihat hasil resep yang diberikan dokter untuk pasien dalam menangani penyakit pasien.

\subsection{PENGUJIAN}

\subsubsection{Pengujian}

Pada bagian pengujian ini akan menerangkan tentang tahapan pengujian pada aplikasi. Metode yang akan dilakukan dalam tahapan pengujian aplikasi ini adalah dengan menggunakan black box. Metode pengujian black box adalah metode pengujian dengan memperhatikan inputan dan hasil yang terjadi sesuai dengan usecase yang telah di rancang.

\subsubsection{TujuanPengujian}

Tujuan dilakukan pengujian adalah untuk mengetahui bahwa fungsi fungsi dalam aplikasi ini sudah sesuai dengan yang di harapkan sesuai dengan rancangan.

\subsubsection{Rencana Pengujian}

Pengujian aplikasi pada tugas akhir ini dilakukan bedasarkan rancangan setiap scenario dari use case. Pengujian juga akan dilakukan secara blackbox pada perangkat sesuai spesifikasi yang ideal. 
JURNAL BUFFER INFORMATIKA

Volume 5 Nomor 2, Oktober 2019

\subsubsection{Hasil Pengujian}

Pengujian ini dilakukan dengan cara menguji aplikasi dari segi fungsionalitas. Pengujian ini bertujuan untuk menemukan kesalahan yang mungkin masih terjadi dalam aplikasi dan untuk mengetahui aplikasi ini sudah sesuai dengan harapan tujuan dibuatnya. Seluruh pengujian sesuai dengan gambar pada bab 5

Tabel 4 Tabel Pengujian Fungsionalitas

\begin{tabular}{|c|c|c|c|c|c|c|}
\hline \multirow{2}{*}{ No } & \multirow{2}{*}{$\begin{array}{l}\text { Fungsion } \\
\text { alitas }\end{array}$} & \multicolumn{2}{|c|}{ Identifikasi } & \multirow{2}{*}{$\begin{array}{l}\text { Hasil } \\
\text { yang di } \\
\text { harapkan }\end{array}$} & \multirow{2}{*}{$\begin{array}{l}\text { Hasil } \\
\text { output }\end{array}$} & \multirow{2}{*}{$\begin{array}{l}\text { Kesimpu } \\
\text { an }\end{array}$} \\
\hline & & \begin{tabular}{|l} 
Kode \\
Kelas \\
Uji
\end{tabular} & \begin{tabular}{|l} 
Kode \\
Butir \\
Uji
\end{tabular} & & & \\
\hline 1. & $\begin{array}{l}\text { Tampilan } \\
\text { Login }\end{array}$ & Req-1.0 & $\begin{array}{l}\mathrm{BU}- \\
01\end{array}$ & $\begin{array}{l}\text { Tampil } \\
\text { menu } \\
\text { login }\end{array}$ & $\begin{array}{l}\text { Tampil } \\
\text { menu } \\
\text { login }\end{array}$ & Berhasil \\
\hline 2. & $\begin{array}{l}\text { Tampilan } \\
\text { view data } \\
\text { pasien }\end{array}$ & $\begin{array}{l}\text { Req- } \\
1.1\end{array}$ & $\begin{array}{l}\mathrm{BU}- \\
02\end{array}$ & $\begin{array}{l}\text { Tampil } \\
\text { data } \\
\text { pasien } \\
\text { berupa } \\
\text { table }\end{array}$ & $\begin{array}{l}\text { Tampil } \\
\text { data } \\
\text { pasien } \\
\text { berupa } \\
\text { able }\end{array}$ & Berhasil \\
\hline 3. & $\begin{array}{l}\text { Tampilan } \\
\text { menu add } \\
\text { data } \\
\text { pasien }\end{array}$ & $\begin{array}{l}\text { Req- } \\
1.2\end{array}$ & $\begin{array}{l}\mathrm{BU}- \\
03\end{array}$ & $\begin{array}{l}\text { Tampil } \\
\text { form add } \\
\text { data } \\
\text { pasien }\end{array}$ & $\begin{array}{l}\text { Tampil } \\
\text { form } \\
\text { add } \\
\text { data } \\
\text { pasien }\end{array}$ & Berhasil \\
\hline 4. & $\begin{array}{l}\text { Tampilan } \\
\text { menu } \\
\text { update } \\
\text { data } \\
\text { pasien }\end{array}$ & $\begin{array}{l}\text { Req- } \\
1.2\end{array}$ & $\begin{array}{l}\mathrm{BU}- \\
04\end{array}$ & $\begin{array}{l}\text { Tampil } \\
\text { form } \\
\text { beserta } \\
\text { beserta } \\
\text { data } \\
\text { sebelumny } \\
\text { a }\end{array}$ & $\begin{array}{l}\text { Tampil } \\
\text { form } \\
\text { beserta } \\
\text { beserta } \\
\text { data } \\
\text { sebelu } \\
\text { mnya }\end{array}$ & Berhasil \\
\hline 5. & $\begin{array}{l}\text { Tampilan } \\
\text { menu } \\
\text { delete } \\
\text { data } \\
\text { pasien }\end{array}$ & $\begin{array}{l}\text { Req- } \\
1.2\end{array}$ & $\begin{array}{l}\mathrm{BU}- \\
05\end{array}$ & $\begin{array}{l}\text { Tampil } \\
\text { table yang } \\
\text { telah } \\
\text { berhasil } \\
\text { didelete }\end{array}$ & $\begin{array}{l}\text { Tampil } \\
\text { table } \\
\text { yang } \\
\text { telah } \\
\text { berhasil } \\
\text { didelete }\end{array}$ & Berhasil \\
\hline 6. & $\begin{array}{l}\text { Tampilan } \\
\text { view table } \\
\text { data } \\
\text { tunggu } \\
\text { pasien(do } \\
\text { kter) }\end{array}$ & $\begin{array}{l}\text { Req- } \\
1.3\end{array}$ & $\begin{array}{l}\mathrm{BU}- \\
06\end{array}$ & $\begin{array}{l}\text { Tampil } \\
\text { table data } \\
\text { pasien dan } \\
\text { action info }\end{array}$ & $\begin{array}{l}\text { Tampil } \\
\text { able } \\
\text { data } \\
\text { pasien } \\
\text { dan } \\
\text { action } \\
\text { info }\end{array}$ & Berhasil \\
\hline 7. & $\begin{array}{l}\text { Tampilan } \\
\text { view table } \\
\text { data } \\
\text { berobat } \\
\text { pasien }\end{array}$ & $\begin{array}{l}\text { Req- } \\
1.4\end{array}$ & $\begin{array}{l}\mathrm{BU}- \\
07\end{array}$ & $\begin{array}{l}\text { Tampil } \\
\text { data } \\
\text { berobat } \\
\text { pasien } \\
\text { berupa } \\
\text { table }\end{array}$ & $\begin{array}{l}\text { Tampil } \\
\text { data } \\
\text { berobat } \\
\text { pasien } \\
\text { berupa } \\
\text { table }\end{array}$ & Berhasil \\
\hline 8. & $\begin{array}{l}\text { Tampilan } \\
\text { menu add } \\
\text { data } \\
\text { berobat } \\
\text { pasien }\end{array}$ & $\begin{array}{l}\text { Req- } \\
1.5\end{array}$ & $\begin{array}{l}\mathrm{BU}- \\
08\end{array}$ & $\begin{array}{l}\text { Tampil } \\
\text { form } \\
\text { inputan } \\
\text { data } \\
\text { berobat } \\
\text { pasien }\end{array}$ & $\begin{array}{l}\text { Tampil } \\
\text { form } \\
\text { inputan } \\
\text { data } \\
\text { berobat } \\
\text { pasien }\end{array}$ & Berhasil \\
\hline 9. & $\begin{array}{l}\text { Tampilan } \\
\text { menu } \\
\text { update } \\
\text { data } \\
\text { berobat }\end{array}$ & $\begin{array}{l}\text { Req- } \\
1.5\end{array}$ & $\begin{array}{l}\mathrm{BU}- \\
09\end{array}$ & $\begin{array}{l}\text { Tampil } \\
\text { form } \\
\text { beserta } \\
\text { beserta } \\
\text { data }\end{array}$ & $\begin{array}{l}\text { Tampil } \\
\text { form } \\
\text { beserta } \\
\text { beserta } \\
\text { data }\end{array}$ & Berhasil \\
\hline
\end{tabular}

p-ISSN : 2527-4856, e-ISSN : 2614-5413

https://journal.uniku.ac.id/index.php/buffer

\begin{tabular}{|c|c|c|c|c|c|c|}
\hline & pasien & & & $\begin{array}{l}\text { berobat } \\
\text { sebelumny } \\
\text { a }\end{array}$ & $\begin{array}{l}\text { berobat } \\
\text { sebelu } \\
\text { mnya }\end{array}$ & \\
\hline 10 & \begin{tabular}{|l} 
Tampilan \\
menu \\
delete \\
data \\
berobat \\
pasien
\end{tabular} & $\begin{array}{l}\text { Req- } \\
1.5\end{array}$ & $\begin{array}{l}\mathrm{BU}- \\
10\end{array}$ & $\begin{array}{l}\text { Tampil } \\
\text { table } \\
\text { berobat } \\
\text { yang telah } \\
\text { berhasil } \\
\text { didelete }\end{array}$ & $\begin{array}{l}\text { Tampil } \\
\text { table } \\
\text { berobat } \\
\text { yang } \\
\text { elah } \\
\text { berhasil } \\
\text { didelete }\end{array}$ & Berhasil \\
\hline 11 & $\begin{array}{l}\text { Tampilan } \\
\text { view } \\
\text { resep } \\
\text { pasien }\end{array}$ & $\begin{array}{l}\text { Req- } \\
1.6\end{array}$ & $\begin{array}{l}\mathrm{BU}- \\
11\end{array}$ & $\begin{array}{l}\text { Tampil } \\
\text { data resep } \\
\text { pasien } \\
\text { berupa } \\
\text { table }\end{array}$ & $\begin{array}{l}\text { Tampil } \\
\text { data } \\
\text { resep } \\
\text { pasien } \\
\text { berupa } \\
\text { table }\end{array}$ & Berhasil \\
\hline
\end{tabular}

Tabel 5 Tabel Pengujian Fungsionalitas Class

\begin{tabular}{|c|c|c|c|c|c|c|c|c|}
\hline \multirow[b]{2}{*}{ No } & \multirow[t]{2}{*}{ Kelas Uji } & \multirow[t]{2}{*}{ Field } & \multirow{2}{*}{$\begin{array}{l}\text { Butir Uji } \\
\text { (Inputan) }\end{array}$} & \multicolumn{2}{|c|}{ Identifikasi } & \multirow{2}{*}{$\begin{array}{l}\text { Jenis } \\
\text { Penguj } \\
\text { an }\end{array}$} & \multirow{2}{*}{$\begin{array}{l}\text { Teknik } \\
\text { Penguji } \\
\text { an }\end{array}$} & \multirow[t]{2}{*}{ Hasil } \\
\hline & & & & $\begin{array}{l}\text { Kode } \\
\text { kelas } \\
\text { uji } \\
\end{array}$ & $\begin{array}{l}\text { Kode } \\
\text { butir } \\
\text { uji }\end{array}$ & & & \\
\hline \multirow[t]{2}{*}{1.} & \multirow[t]{2}{*}{$\begin{array}{l}\text { Login } \\
\text { user / } \\
\text { password }\end{array}$} & $\begin{array}{l}\text { User } \\
\text { Name }\end{array}$ & $\begin{array}{l}\text { Sesuai dengan } \\
\text { inputan } \\
\text { database }\end{array}$ & $\begin{array}{l}\text { Req- } \\
1.0\end{array}$ & $\begin{array}{l}\mathrm{BU}- \\
01\end{array}$ & Sistem & $\begin{array}{l}\text { Black } \\
\text { pox }\end{array}$ & Sukses \\
\hline & & Password & $\begin{array}{l}\text { Sesuai dengan } \\
\text { inputan } \\
\text { database }\end{array}$ & $\begin{array}{l}\text { Req- } \\
1.0\end{array}$ & $\begin{array}{l}\mathrm{BU}- \\
01\end{array}$ & Fistem & $\begin{array}{l}\text { Black } \\
\text { pox }\end{array}$ & Sukses \\
\hline \multirow[t]{4}{*}{2.} & \multirow{4}{*}{$\begin{array}{l}\text { Form add } \\
\text { data } \\
\text { pasien }\end{array}$} & \multirow[t]{3}{*}{$\begin{array}{l}\text { Nama } \\
\text { pasien }\end{array}$} & Tidak kosong & $\begin{array}{l}\text { Req- } \\
1.2\end{array}$ & $\begin{array}{l}\mathrm{BU}- \\
03\end{array}$ & Sistem & $\begin{array}{l}\text { Black } \\
\text { pox }\end{array}$ & Sukses \\
\hline & & & $\begin{array}{l}\text { Length > } 2 \\
\text { Ex : ade }\end{array}$ & $\begin{array}{l}\text { Req- } \\
1.2\end{array}$ & $\begin{array}{l}\text { BU - } \\
03\end{array}$ & Sistem & $\begin{array}{l}\text { Black } \\
\text { pox }\end{array}$ & Sukses \\
\hline & & & $\begin{array}{l}\text { Length }<35 \\
\text { Ex : ade kana } \\
\end{array}$ & $\begin{array}{l}\text { Req- } \\
1.2 \\
\end{array}$ & $\begin{array}{l}\mathrm{BU}- \\
03\end{array}$ & Sistem & $\begin{array}{l}\text { Black } \\
\text { box }\end{array}$ & Sukses \\
\hline & & Alamat & Tidak Kosong & $\begin{array}{l}\text { Req- } \\
1.2 \\
\end{array}$ & $\begin{array}{l}\text { BU - } \\
03 \\
\end{array}$ & Sistem & $\begin{array}{l}\text { Black } \\
\text { box }\end{array}$ & Sukses \\
\hline \multirow[t]{7}{*}{3.} & \multirow{7}{*}{$\begin{array}{l}\text { Add data } \\
\text { pemeriksa } \\
\text { an pasien }\end{array}$} & \multirow[t]{2}{*}{ Keluhan } & Tidak Kosong & $\begin{array}{l}\text { Req- } \\
1.4 \\
\end{array}$ & $\begin{array}{l}\mathrm{BU}- \\
08 \\
\end{array}$ & Sistem & $\begin{array}{l}\text { Black } \\
\text { box }\end{array}$ & Sukses \\
\hline & & & \begin{tabular}{|l|} 
Length > 3 \\
Ex : sakit \\
kepala \\
\end{tabular} & $\begin{array}{l}\text { Req- } \\
1.4\end{array}$ & $\begin{array}{l}\mathrm{BU}- \\
08\end{array}$ & Sistem & $\begin{array}{l}\text { Black } \\
\text { pox }\end{array}$ & Sukses \\
\hline & & \multirow[t]{2}{*}{\begin{tabular}{|l|} 
Diagnosa \\
Penyakit
\end{tabular}} & Tidak Kosong & $\begin{array}{l}\text { Req- } \\
1.4 \\
\end{array}$ & $\begin{array}{l}\mathrm{BU}- \\
08\end{array}$ & Sistem & $\begin{array}{l}\text { Black } \\
\text { box }\end{array}$ & Sukses \\
\hline & & & \begin{tabular}{|l} 
Length $>3$ \\
Ex : terkena \\
gejala dbd \\
\end{tabular} & $\begin{array}{l}\text { Req- } \\
1.4\end{array}$ & $\begin{array}{l}\mathrm{BU}- \\
08\end{array}$ & Sistem & $\begin{array}{l}\text { Black } \\
\text { pox }\end{array}$ & Sukses \\
\hline & & \multirow[t]{2}{*}{$\begin{array}{l}\text { Tindakan } \\
\text { Medis }\end{array}$} & Tidak Kosong & $\begin{array}{l}\text { Req- } \\
1.4 \\
\end{array}$ & $\begin{array}{l}\mathrm{BU}- \\
08 \\
\end{array}$ & Sistem & $\begin{array}{l}\text { Black } \\
\text { box }\end{array}$ & Sukses \\
\hline & & & $\begin{array}{l}\text { Length > } 3 \\
\text { Ex : } \\
\text { pemeriksaan } \\
\text { standart }\end{array}$ & $\begin{array}{l}\text { Req- } \\
1.4\end{array}$ & $\begin{array}{l}\mathrm{BU}- \\
08\end{array}$ & Sistem & $\begin{array}{l}\text { Black } \\
\text { pox }\end{array}$ & Sukses \\
\hline & & \begin{tabular}{|l|}
$\begin{array}{l}\text { Resep } \\
\text { obat }\end{array}$ \\
\end{tabular} & Tidak Kosong & $\begin{array}{l}\text { Req- } \\
1.4 \\
\end{array}$ & $\begin{array}{l}\mathrm{BU}- \\
08\end{array}$ & Sistem & $\begin{array}{l}\text { Black } \\
\text { pox }\end{array}$ & Sukses \\
\hline
\end{tabular}

\section{KESIMPULAN}

Bedasarkan pengujian yang telah dilakukan pada aplikasi ini, maka dapat mengambil kesimpulan, bahwsannya aplikasi ini :

1. Mampu mengatasi masalah dalam pendataan pasien yang datang berobat tanpa harus mengeluarkan banyak kertas.

2. Mampu melakukan pendataan secara rapih sehingga meningkatkan pelayanan terhadap masyarakat yang melakukan berobat di apotek. 
JURNAL BUFFER INFORMATIKA

Volume 5 Nomor 2, Oktober 2019

\section{SARAN}

Pada buku ini sudah dijelaskan dengan baik analisis dan perancangan pembuatan aplikasi ini. Namun, aplikasi ini masih sepenuhnya membantu dalam mengatasi masalah yang terjadi dalam aktivitas pengelolaan data pasien di apotek, maka saran bagi pengembang yang ingin melakukan upgrade pada aplikasi adalah :

1. Membuat control panel untuk segala pengaturan ip server pada aplikasi.

2. Dapat melakukan penambahan user dalam penggunaan apllikasi atau melakukan pengelolaan user dalam pengelolaan.

3. Melakukan perbaikan penampilan atau design lebih baik dengan listview.

4. Melakukan perbaikan penampilan atau design aplikasi sehingga tidak terlalu polos.

\section{DAFTAR PUSTAKA}

[1] Hermawan, S. (2011). mudah membuat aplikasi android. (T. A. Prabawati, Ed.) Salatiga: ANDI Yogyakarta.

[2] Safaat, N. (2011). ANDROID (Pemrograman Aplikasi Mobile Smartphone dan Tablet PC berbasis Android). Bandung: Informatika Bandung.

[3] Puspitasari. (2011). Pemrograman Web Database dengan PHP \& MySQL. Jakarta: Skripta.

[4] Chuzaimah, M. \&. (2010). SMARTPHONE: ANTARA KEBUTUHAN DAN ELIFESTYLE. Jurnal Seminar Nasional Informatika.

[5] S, A. (2004). Sistem Informasi Manajemen Konsep dan Pengembangannya. Bandung: Lingga Jaya.

[6] Gartina, I. (2009). Analisis dan Desain Sistem Informasi. Bandung: Coursware Politeknik Telkom.

[7] Amir, a. (1997). Bunga Rampai Hukum Kesehatan. jakarta: widya medika.
p-ISSN : 2527-4856, e-ISSN : 2614-5413

https://journal.uniku.ac.id/index.php/buffer

[8] Kartini, B. U. (2013). Perancangan

Sistem Informasi Pemesanan

TiketKonser Musik Online Berbasis Lokasi. Yogyakarta: Prosiding Seminar. 